\title{
イソペンテニルメシチルオキシド並びにその 加水分解によるメチルヘプテノンの合成
}

\author{
大道弘昭・宮腰哲雄・斎藤鐘次郎 \\ 明治大学工学部工業化学科 (神奈川県川崎市多摩区東三田 1-1-1)
}

Synthesis of Isopentenyl Mesityl Oxide and Its Hydrolysis to Methylheptenone

\author{
Hiroaki Omichi, Tetsuo Miyakoshi, and Shojiro Saito \\ Department of Industrial Chemistry, Faculty of Engineering, Meiji University \\ (1-1-1, Higashimita, Tama-ku, Kawasaki-shi, Kanagawa-ken)
}

\begin{abstract}
Alkylation of mesityl oxide (7) with 1-chloro-3-methy1-2-butene (1) using potassium or sodium hydroxide in an aprotic solvent afforded a mixture of isopentenyl mesityl oxide, (4), (5) and (9) in $83 \%$ yield, which were hydrolytically decomposed to 6-methyl-5-hepten-2-one (3) in $95 \%$ yield in an autoclave.
\end{abstract}

\section{1 緒 言}

1-クロロ-3-メチル-2-ブテン（1）とアセトン（2）とか ら, 直接アルキル化によって 6-メチル-5-ヘプテン-2オン（3）（メチルヘプテノンと略称する）を合成する反 応は，すでに工業的にも行われている反応であるが，3イソプロペニル-6-メチル-5-ヘプテン-2-オン (4), 3-イ ソプロピリデン-6-メチル-5-ヘプテン-2-オン(5) [(4), (5) 及び（9）をイソペンテニルメシチルオキシドと略称 する]，3-イソペンテニル-6-メチル-5-ヘプテン-2-オン （6）などを副反応生成物として生成する ${ }^{1)}($ Sche me-1)。<smiles>CC(=O)CCC=C(C)C</smiles>

(1)

(2)

(3)<smiles>C=C(C)C(CC=C(C)C)C(C)=O</smiles>

(4)<smiles>CC(=O)C(CC=C(C)C)=C(C)C</smiles>

(5)

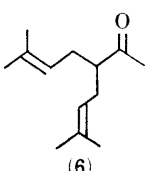

(6)
Scheme-1

著者らはこれらの副反応生成物の利用について検討を 加えてきたが，今回（4）及び（5）の逆アルドール反応 によって（3）を得る方法について報告する。

（4）または（5）から逆アルドール反応によって（3）を 得る試みは, すでに酸触媒による方法 ${ }^{2}$ のほか, アルカ リ触媒やアミン類の存在で行ら若干の特許 ${ }^{3)}$ がある。し
かしながら，酸触媒による方法では，副反応のためにう まく進行しないことが報告されており，また特許では詳 細が不明な点が多い。このため著者らはアルカリ触媒の 存在下オートクレーブ中で加圧加熱する方法で分解を試 みた。

（4）及び（5）は，(1) とメシチルオキシド（7）との アルキル化反応によって直接合成され, 液安中ナトリウ ムアミドによる方法 ${ }^{4)}$, 相間移動触媒を用いる方法 ${ }^{5)}$ のほ か若干の特許 ${ }^{6)}$ が見られる。著者らは水酸化アルカリを 塩基として使用し，非プロトン性極性溶媒中で（1）と (7) との直接アルキル化反応により合成した (Scheme2)。この際の反応条件についても併せて報告する。<smiles>C=C(C)C(CC=C(C)C)C(C)=O</smiles>

(4)<smiles>CC(=O)C(CC=C(C)C)=C(C)C</smiles>

(5)<smiles></smiles>

(7)
Scheme-2

\section{2 実 験}

\section{$2 \cdot 1$ 試薬}

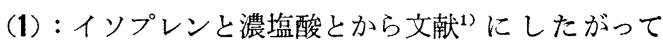
合成した。bp 53.5 54 ${ }^{\circ} \mathrm{C} / 100 \mathrm{mmHg}$, 純度 $99 \%$ (GLC)。

(7) : ジアセトンアルコールに少量のリン酸を加え脱 
水後分留して精製した。bp $128 \sim 129^{\circ} \mathrm{C}$ 。 4 -メチル-4-ペ ンテン-2-オン（8）を $5 \%$ 含む (GLC)。

$\mathrm{KOH}$ 及び $\mathrm{NaOH}$ : 粉末状にして使用した。純度それ ぞれ 78.55\%，89.68\% (滴定)。

その他の試薬は市販品をそのまま使用した。

\section{$2 \cdot 2$ (1) と（7）とのアルキル化反応}

還流冷却器, 温度計, かきまぜ機を備えた三つロフラ スコに, 所定量の $\mathrm{KOH}$, 水, 溶媒, (1) 及び (7) を加 え， $60^{\circ} \mathrm{C}$ で所定時間かきまぜながら反応させた。反応 後室温に冷却, 水 $20 \mathrm{ml}$ を加え, エーテルで抽出 $(10$ $\mathrm{ml} \times 2)$, 水洗 $(10 \mathrm{ml})$, 硫酸ナトリウム (無水物) で乾 燥後, エーテルを留去し, 残部をシリカゲルクロマトグ ラフィーにより精製し，GLC によって分析し収率を求 めた。

\section{$2 \cdot 3$ （5）の加水分解による（3）の合成}

直径 $2 \mathrm{~cm}$, 長さ $9 \mathrm{~cm}$ の小さな 円筒形ステンレス製 オートクレーブ (内容積約 $30 \mathrm{ml}$ ) に, 所定量の (5),

$10 \% \mathrm{NaOH}$ 及び溶媒を加え, 所定温度に一定時間静置 して反応させた。反応後室温に冷却, 反応物をエーテル で抽出 $(10 \mathrm{ml} \times 2)$, 水洗 $(10 \mathrm{ml})$, 硫酸ナトリウム（無 水物) で乾燥後, エーテルを留去し, 残部をシリカゲル クロマトグラフィーにより精製し，GLC によって分析 し収率を求めた。

\section{3 結果及び考察}

$3 \cdot 1$ (1) と（7）とのアルキル化反応

$3 \cdot 1 \cdot 1$ アルキル化反応生成物について

反応生成物のガスクロマトグラムの一例を Fig.-1 に 示した。Fig.-1 に見られるように，主反応生成物であ る (4)，(5)，(9) のほかに, かなり多数の副反応生成物 を生ずる。

水を添加してアルキル化を行うと，（1）の加水分解生

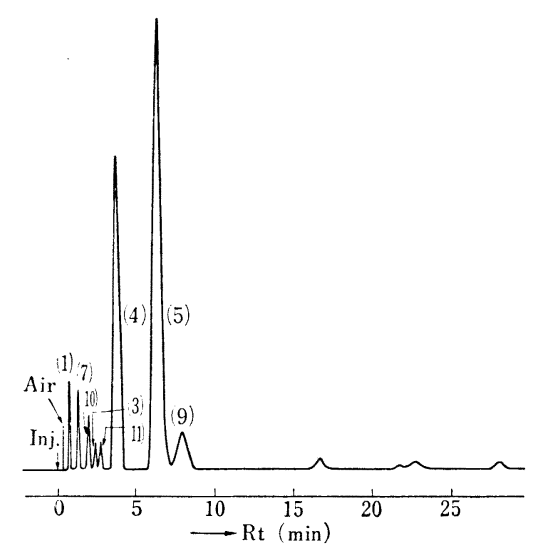

PEG 20.1 (20\% on Celite 545, 60 80 mesh), $1.2 \mathrm{~m}, 160^{\circ} \mathrm{C}$, He $0.6 \mathrm{~kg} / \mathrm{cm}^{2}$

Fig.-1 Gaschromatogram of the product.
成物である 3-メチル-2-ブテン-1-オール（10）ならびに そのアルキル化物である 3-メチル-2-ブテニルエーテル (11)のほか, 主反応生成物の一部が逆アルドール反応に よって生じたと考えられる（3）などが副生する。

Rt 16 min 以上に現れるピークはいずれも MS に颃い て $\mathrm{M}^{+}=234$ を示すところから, ジアルキル化物と推定 されるが，構造その他については検討中である。

$3 \cdot 1 \cdot 2 \quad(4) \rightleftarrows(5)$ の異性化反応について

（4）及び (5) は，水酸化アルカリの存在下に狲て急 速に異性化する。この事実を Table-1 に示した。

Table-1 は，それぞれ純粋な（4）及び（5） $1 \mathrm{~g}$ に， $0.1 \mathrm{~g}$ の $\mathrm{KOH}$ を加え, $60^{\circ} \mathrm{C}$ に保ったときの異性化の 経時変化を GLC 分析により追跡したものである。

したがって，アルキル化に際して水酸化アルカリを （1）に対して過㮃に使用すると，反応の終末時において 過㮃の水酸化アルカリが存在する結果となり，(5) が主 反応生成物として得られるものと推察される。

\section{$3 \cdot 1 \cdot 3 （ 4) ，(5)$ の生成比と反応時間との関係}

Table-2 は，(4)，(5) の生成比と反応時間との関係 を示したものである。すなわち，(1)，(7)， $\mathrm{KOH}$ 及び 水をそれぞれ $1 \mathrm{~g}$ ずつ使用し, ジメチルスルホキシド (DMSO) $5 \mathrm{ml}$ を加えて $60^{\circ} \mathrm{C}$ でアルキル化を行ったと き，反応時間をそれぞれ $5,10,20,30 \mathrm{~min}$ で打ち切り， 所定の方法で処理した生成物を GLCにより分析したも のである。

Table-2 によれば，収率にはさほど大差はないにも かかわらず, 反応の初期においては (4) が, また時間の 経過とともに(5) が, 主反応生成物となっている。

Table-1 ならびに Table-2 の結果から，(1) と(7)

Table-1 Isomerization reaction between (4) and (5).

\begin{tabular}{c|r|c|c|c}
\hline \multirow{2}{*}{ Time } & \multicolumn{4}{|c}{ Distribution (\%) } \\
\cline { 2 - 5 }$(\min )$ & \multicolumn{2}{|c|}{ (4) } & \multicolumn{2}{|c}{ (5) } \\
\hline 0 & (4) & (5) & (4) & (5) \\
\hline 5 & 100 & 0 & 0 & 100 \\
10 & 71 & 29 & 24 & 76 \\
20 & 49 & 51 & 30 & 70 \\
30 & 40 & 60 & 35 & 65 \\
60 & 40 & 60 & 35 & 65 \\
& 40 & 60 & 35 & 65 \\
\hline
\end{tabular}

Table-2 Effect of the reaction time on the distribution of products.

\begin{tabular}{c|c|c|c|c}
\hline \multirow{2}{*}{$\begin{array}{c}\text { Reaction time } \\
(\min )\end{array}$} & $\begin{array}{c}\text { Yield } \\
\text { (\%) }\end{array}$ & \multicolumn{3}{|c}{ Distribution (\%) } \\
\cline { 3 - 5 } & (4) & (5) & (9) \\
\hline 5 & 50 & 71 & 24 & 5 \\
10 & 54 & 30 & 65 & 5 \\
20 & 54 & 26 & 68 & 6 \\
30 & 57 & 27 & 68 & 5 \\
\hline
\end{tabular}



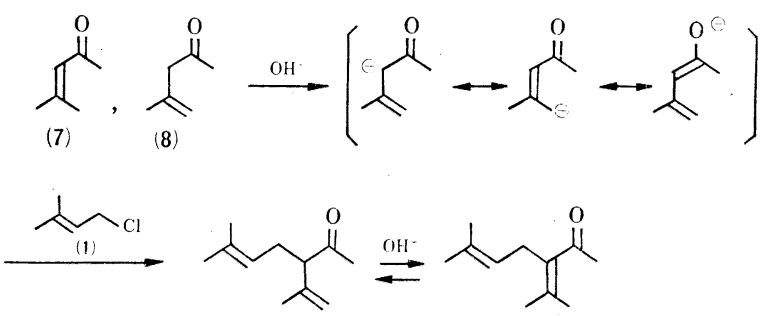

(4)

(5)

Scheme-3

とのアルキル化反応においては, 最初に（4) が生成し, ついで過剰の水酸化アルカリの存在下 (5) に異性化する ものと推察される（Scheme-3）。

$3 \cdot 1 \cdot 4$ アルキル化の反応条件と収率との関係

Table-3 は, 反応温度を $60^{\circ} \mathrm{C}$ として, アルキル化の 反応条件とモノアルキル化物の収率との関係を検討した ものである。

反応溶媒としては, DMSO とへキサメチルホスホル アミド (HMPA) がほぼ同程度の効果を示したが, ジメ チルホルムアミド, テトラヒドロフラン, メチルセロソ ルブ,アセトン, ベンゼンなどはほとんど効果は認めら れなかった。

反応系に水を添加すると, 反応中水酸化アルカリの固 化を防止し，かきまぜを容易にかつ均等に行える利点が ある。しかし収率は若干低下する（Run 5，7）。

（1）を過剰に使用した場合（Run 3，4）と（7）を過 剩に使用した場合（Run 5，6）とでは, 後者の方が若干 収率が向上した。

（4）が主反応生成物として得られたのは，Run 3 と Run 9 とである。Run 3 では（1）を過剩に使用したた め $\mathrm{KOH}$ がすべて消費され，3・1.2 で述べた異性化が起 こらなかったものと推察される。これに対し, Run 9 で 見られるように, HMPA を反応溶媒に使用したときは, 常に（4）が主反応生成物として得られる事実から，この 場合は HMPA の溶媒効果によるものと考えられる。 最もよい結果が得られたのは, Run 8 に見られるよう
に, $\mathrm{NaOH}$ を無水の状態で使用してアルキル化を行 った場合で，収率 $83 \%$ であった。

\section{$3 \cdot 2$ （5）の加水分解による（3）の合成}

\section{$3 \cdot 2 \cdot 1$ 加水分解反応 概要}

イソアミルメシチルオキシド（3-イソプロピリデ ン-6-メチル-2-ヘプタノン）のようなアルキルメシ チルオキシド類を酸で加水分解して, メチルケトン 類を合成する報告 ${ }^{2}$ があるが，（5）を硫酸酸性水溶 液で加水分解すると，多数の環化生成物が得られ る7。 。でに $3 \cdot 1 \cdot 1$ で述べたように，アルキル化の 際の副反応生成物として少量の (3) が得られる事実は, 一部モノアルキル化物の逆アルドール反応が起こったも のと考えられる。このため水酸化アルカリを使用して （5）の加水分解を試みたが収率の向上が認められなかっ たので，オートクレーブを使用した。

水酸化アルカリを使用する加水分解反応では, 生成物 は主として（2）と（3）であって，副反応生成物はほと んど得られず，収率が低いときは未反応原料を回収し た。溶媒として市販メタノールを添加して行うと，(3) の還元生成物である 6-メチル-5-ヘプテン-2-オールが 数\%副生したが，理由については現在検討中である。

$3 \cdot 1 \cdot 2$ で述べたように，(4) と（5）とは水酸化アルカ リの存在で互いに異性化するので，原料としては（4）ま たは（5）のいずれを使用してもほぼ同じ結果が得られ た。また 3.1 で述べたモノアルキル化物 (4), (5) 及び （9）の混合物 [(9) $40 \%$ を含む] を原料として使用し ても，好収率で（3）が得られ（9）は回収されなかった 事実より（9）も同様な条件で（3）に加水分解されるも のと推察される。

（4）及び（5）の加水分解は Scheme-4 のように進行 するものと推定される。

$3 \cdot 2 \cdot 2$ 加水分解の反応条件と収率との関係

Table-4 に加水分解反応の条件と収率との関係を示 した。

$3 \cdot 2 \cdot 3$ 反応温度と収率との関係

反応温度と収率との関倸を求めたところ， Run $1 \sim 3$

Table-3 Alkylation of mesityl oxide (7) with 1-chloro-3-methyl-2-butene (1).

\begin{tabular}{c|c|c|c|c|c|c|c|c|c|c|c}
\hline Run & $\begin{array}{c}(\mathbf{1}) \\
(\mathbf{g})\end{array}$ & $\begin{array}{c}(\mathbf{7}) \\
(\mathrm{g})\end{array}$ & $\begin{array}{c}\text { Alkali } \\
(\mathrm{g})\end{array}$ & $\begin{array}{c}\mathrm{H}_{2} \mathrm{O} \\
(\mathrm{ml})\end{array}$ & $\begin{array}{c}\text { Solvent } \\
(\mathrm{ml})\end{array}$ & $\begin{array}{c}\text { Temp. } \\
\left({ }^{\circ} \mathrm{C}\right)\end{array}$ & $\begin{array}{c}\text { Time } \\
(\mathrm{min})\end{array}$ & $\begin{array}{c}\text { Yield } \\
(\%)\end{array}$ & \multicolumn{2}{|c|}{ Product distribution (\%) } \\
\hline 1 & 1 & 1 & $\mathrm{KOH} 1$ & 1 & DMSO 5 & 60 & 30 & 57 & 27 & 68 & 5 \\
2 & 1 & 1 & $\mathrm{KOH} 2$ & 1 & DMSO 5 & 60 & 30 & 62 & 28 & 70 & 2 \\
3 & 2 & 1 & $\mathrm{KOH} 1$ & 1 & DMSO 5 & 60 & 30 & 61 & 70 & 22 & 8 \\
4 & 2 & 1 & $\mathrm{KOH} 2$ & 1 & DMSO 5 & 60 & 30 & 65 & 29 & 69 & 2 \\
5 & 1 & 2 & $\mathrm{KOH} 1$ & 1 & DMSO 5 & 60 & 30 & 64 & 26 & 68 & 6 \\
6 & 1 & 2 & $\mathrm{KOH} 2$ & 1 & DMSO 5 & 60 & 30 & 73 & 26 & 69 & 5 \\
7 & 1 & 2 & $\mathrm{KOH} 1$ & 0 & DMSO 5 & 60 & 30 & 72 & 27 & 69 & 4 \\
8 & 1 & 2 & $\mathrm{NaOH} 1$ & 0 & DMSO 5 & 60 & 30 & 83 & 28 & 71 & 1 \\
9 & 1 & 2 & $\mathrm{KOH} 1$ & 1 & HMPA 5 & 60 & 60 & 63 & 57 & 38 & 5 \\
\hline
\end{tabular}




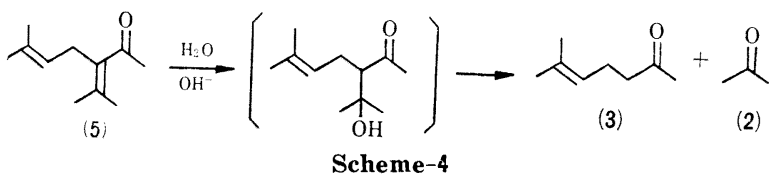

Table-4 Hydrolysis of 3-isopropeny 1-6-methyl-5-hepten-2-one (4) and 3-isopropyliden-6-methyl-5-hepten-2-one (5) to 6-methyl-5-hepten-2-one (3).

\begin{tabular}{|c|c|c|c|c|c|c|}
\hline Run & $\begin{array}{l}\text { (4) or (5) } \\
(\mathrm{ml})\end{array}$ & $\begin{array}{c}10 \% \mathrm{NaOH} \\
(\mathrm{ml})\end{array}$ & $\begin{array}{l}\text { Solvent } \\
(\mathrm{ml})\end{array}$ & $\begin{array}{c}\text { Temp. } \\
\left({ }^{\circ} \mathrm{C}\right)\end{array}$ & $\begin{array}{l}\text { Time } \\
(\mathrm{h})\end{array}$ & $\begin{array}{l}\text { Yield } \\
(\%)\end{array}$ \\
\hline 1 & (5) 5 & 2 & $\mathrm{Me}_{2} \mathrm{CO} 1$ & 200 & 12 & 5 \\
\hline 2 & (5) 5 & 2 & $\mathrm{Me}_{2} \mathrm{CO} 1$ & 240 & 12 & 20 \\
\hline 3 & (5) 5 & 2 & $\mathrm{Me}_{2} \mathrm{CO} 1$ & 260 & 12 & 85 \\
\hline 4 & (5) 5 & 2 & $\mathrm{Me}_{2} \mathrm{CO} 1$ & 260 & 6 & 25 \\
\hline 5 & (5) 5 & 2 & None & 260 & 12 & 20 \\
\hline 6 & (5) 5 & 5 & None & 260 & 12 & 40 \\
\hline 7 & (5) 5 & 5 & $\mathrm{Me}_{2} \mathrm{CO} 1$ & 260 & 12 & 95 \\
\hline 8 & (5) 5 & 5 & $\mathrm{MeOH} 1$ & 260 & 12 & $90^{\mathrm{a})}$ \\
\hline 9 & (4) 5 & 5 & THF 0.8 & 260 & 12 & 80 \\
\hline
\end{tabular}

a) In this case, 6-methyl-5-hepten-2-ol (3\%) was obtained as a by-product.

に示すように, $200^{\circ} \mathrm{C}$ では $5 \%, 240^{\circ} \mathrm{C}$ では $20 \%$ と低 く, $260^{\circ} \mathrm{C}$ で $85 \%$ に達した。このように（5）の加水分 解反応は, $260^{\circ} \mathrm{C}$ というかなり高い温度が必要である。 $3 \cdot 2 \cdot 4$ 反応時間と収率との関係

反応時間と収率との関係は，Run 3 及び Run 4 にみ られるように，6h では $25 \%$ と低いが，12h では $85 \%$ に達する。このように反応時間もかなり長時間が必要で ある。

\section{$3 \cdot 2 \cdot 5$ アルカリの使用量ならびに溶媒の影響}

水酸化アルカリのみで加水分解を行った場合, 水酸化 アルカリの使用量をふやすと収率は若干向上した（Run 5 及び 6)。しかしアルカリの使用量をさらにふやすと， 重合物が増加し, 収率は逆に低下する結果が得られた。 アセトン，メタノール，テトラヒドロフラン (THF) などの溶媒を少量添加すると，収率は飛躍的に向上した (Run 3·7·8 及び 9)。理由については不明であるが，(5) の水酸化アルカリ水溶液に対する溶解度が, これらの溶 媒の添加によって増加するためではないかとも考えられ
る。

\section{4 総括}

メシチルオキシド (7) はテルペン化合物の合成 原料として古くより使用されてきた。筆者らはイ ソペンテニルメシチルオキシドを得る目的で, （1）と（7）とのアルキル化を非プロトン性極性溶 媒中で行い, 反応条件と収率との関係を検討し, 収率 $83 \%$ でモノアルキル化物 (4)，(5) 及び (9) を得ることができた。

$$
\text { 一方，メチルヘプテノン (3) はテルペン化合物 }
$$
合成の重要な中間体であり，その合成は(1)と（2) とのアルキル化による方法でも行われている。し たがって，その際副生する (4)，(5) 及び（6）の 有効な利用法の開発も充分検討を要する問題であ ろう。

このような観点から，モノアルキル化物 (4)， （5）及び $(\mathbf{9})$ の (3) への変換を目的とし, 水酸化 アルカリの存在でオートクレーブ中で加水分解を 行い, 反応条件と収率との関係を検討した結果，収率 95\%で（3）を得た。

\section{(昭和 58 年 4 月 23 日受理) \\ 文献}

1) 大道弘昭, 斎藤鐘次郎, 有合化, 28, 54 (1970)

2) M. Matsui, T. Yoshida, Agr. Biol. Chem., 28, 105 (1964)

3）例えば R.S. DeSimone, US Pat., 3,976,700 (1977)

Rhone-Poulenc, S. A., Fr. Demande, 2,315,495 :

Chem. Abstr., 87, 101946 q (1977)

S.T. Murayama, US Pat., 4,153,634 (1979)

P.S. Gradeff, M.R. Angeles, US Pat., 4,153,633 (1979)

4) M. Matsui, T. Yoshida, H. Mori, Agr. Biol. Chem., 28, 95 (1964)

5) Y. Fujita, F. Wada, T. Onishi, T. Nishida, Chem. Lett., 1977, 945

6）例えばクラレ，公開特許，昭 49-25926; Kuraray, US Pat., 3, 983,175 (1977)

7）茶谷道夫, 斎藤鐘次郎, 大道弘昭, 宮腰哲雄, 第 15 回香 料・テルペンおよび精油化学に関する討論会講演要旨集 (1971) p. 229 